
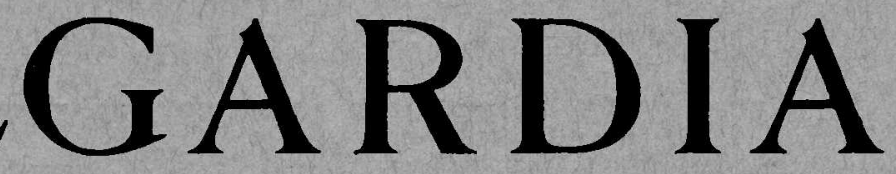

A Journal of Agricultural Science Published by the California Agricultural Experiment Station

\title{
CONTENTS
}

\section{LYGUS BUG INJURY AND ITS EFFECT ON THE GROWTH OF ALFALFA}

\author{
LEE R. JEPPSON and G. F. MACLEOD
}

\section{THE WILLAMETTE MITE ON GRAPES}

NORMAN W. FRAZIER and LESLIE M. SMITH 


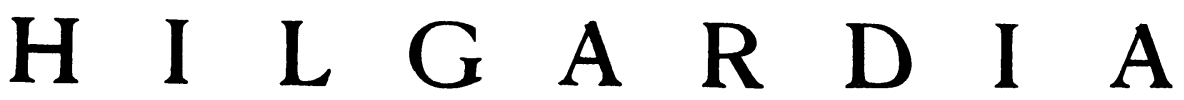 \\ A Journal of Agricultural Science Published by \\ the California Agricultural Experiment Station}

VoL. 17

NOVEMBER, 1946

No. 4

\section{LYGUS BUG INJURY AND ITS EFFECT ON THE GROWTH OF ALFALFA}

LEE R. JEPPSON ${ }^{2}$ AND G. F. MACLEOD 3

\section{HISTORY OF THE PROBLEM}

THE GROUP of hemipterous insects belonging to the genus Lygus, of the family Miridae, has long been recognized as injurious to many agricultural crops and ornamental plants. In the past fifteen years two species of this genusL. hesperus Knight and L. elisus Van Duzee-have been shown to cause flower drop and injury to pods and seeds of beans (Shull, 1933) $;^{4}$ flower drop and shriveled seed in alfalfa (Sorenson, 1936, 1939 ; Shull, Rice, and Cline, 1934) and sugar beets (Hills, 1941; Hills, 1943) ; and shedding of the squares and other injury to cotton (McGregor, 1927; Ewing, 1929 ; Cassidy and Barber, 1939). As a result of these findings much information has been accumulated on the biology of these insects in relation to each of these host crops (Shull, 1933; Sorenson, 1939; and Smith, 1942).

The relation of lygus bugs to flower drop and shriveled seed of alfalfa has been the subject of extensive investigations by Sorenson $(1932,1939)$, Shull, Rice, and Cline (1934), Carlson (1940), and Stitt (1940), in which they have shown the importance of these insects in limiting alfalfa seed production.

Shull, Rice, and Cline (1934) were the first to suggest that lygus bugs might be a factor in alfalfa hay production. In their experiments, they put cages over four areas, each of which had from 17 to 20 plants. Two of these plots served as checks; on the others a population of bugs was maintained. An average of $\mathbf{1 7 . 5}$ per cent less hay was produced in the infested than in the check cages. Sorenson (1939) confined lygus bugs on alfalfa plants, and measured the lengths of the stems at various intervals. He found 8 to 35 per cent reduction in the length of the stems as a result of injuries caused by the bugs.

After the present study was under way, Carlson (1940) published investigations in which he measured the stem lengths of plants which had been grown in the field and kept free from lygus bugs by being dusted five to seven times a week with a pyrethrum-sulfur mixture. Upon comparing the stems of pro-

\footnotetext{
${ }^{1}$ Received for publication July 5, 1945.

${ }^{2} \mathrm{Junior}$ Entomologist in the Experiment Station.

s Professor of Entomology and Entomologist in the Experiment Station; resigned July 1, 1945.

"See "Literature Cited" for complete citations, referred to in the text by author and date of publication.
} 
tected plants with those of naturally infested plants he found an average difference in length of 6.8 inches in 22 days of growth. He observed, however, an increase in the number of stems-from 24 on protected plants to 40 on infested plants-but the number of leaves on the stems were about equal. This would indicate that the insect injury resulted in more stems but shorter lengths. Carlson also found that the air-dried forage of plants continuously infested with lygus bugs weighed significantly more than that from plants uninfested from the prebud stage until seed harvest.

From this review of earlier work, it is apparent that the investigators are not agreed on the extent of injury done by this group of insects to the vegetative growth of alfalfa. Neither is it possible by field observation to determine whether or not there is definite reduction in yield of forage alfalfa attributable to lygus bugs. This paper reports the results of greenhouse studies on the effect of feeding by lygus bugs on the total growth of alfalfa plants, and the nature of the feeding injury to the plant tissues.

\section{HISTOLOGICAL STUDIES OF LYGUS BUG INJURY TO ALFALFA PLANT TISSUES}

It is well known that lygus bugs usually feed at the growing tips, the internodes, and on the flowers and seeds of alfalfa plants. Although Carlson (1940) has adequately studied the effects of lygus bug feeding on flower buds and seeds, no information was available on the effects of injury by these insects upon the vegetative growth of alfalfa plants. Accordingly, histological studies of injured and normal-growth shoots of alfalfa plants were inaugurated.

The alfalfa stems used to study the nature of the damage to the growing tips were taken from artificially infested plants. The stems of potted alfalfa plants were cut $2 \frac{1}{2}$ inches above the crown. The plants were immediately caged and given opportunity to grow until the stems reached a length of 2 to 10 inches-according to the height desired - at which time 20 to 25 lygus bugs were introduced into the cages. After the plants had been exposed for 12 hours the bugs were removed and the plants recaged. Two or three terminal buds were removed after 24, 48, and 96 hours, and fixed in formalin-aceticacid-alcohol for histological study. The buds were imbedded in paraffin, sectioned by the ordinary methods, and stained with iron hematoxylin at $\mathrm{pH} 1.4$ according to the technique described by Craig and Wilson (1937).

Carlson (1940) found a collarlike area of discoloration surrounding a small perforation at the point where the insect's stylets had penetrated. Complete disintegration had followed, and this had resulted in the death of the injured buds. Carlson observed that dead buds frequently remained attached to the floral axis, more or less retaining the size and shape they had at the time of injury.

In these studies disintegration and complete breakdown of the young ovary were indicated in sections made of injured alfalfa flower buds. Plate $1, A$, shows a raceme with several young ovaries that were completely disintegrated. An uninjured raceme is shown in $B$. Sections made of apical growing regions, axillary stems, and leaf primordia show a similar disorganization of the tissue surrounding the puncture made by the insect's stylets, and a complete disintegration of a relatively large area of meristematic tissue at 
the growing regions-terminal and lateral buds (plates 2 and 3). Observations made of injured stems indicate that stem elongation continues, though somewhat retarded, unless the new growth is impaired by continued insect feeding. This increase in stem length appears to take place either by a substitution of lateral bud primordia for the normal growing tip or by the regeneration of a new growing region from uninjured meristematic cells near the area of injury. Pilkington (1929) found that a regeneration took place in Vicia $F a b a$ and Lupinus albus after a considerable portion of the terminal meristem was injured. She states, "It is probable that not only that part of the growing point which lies above the youngest primordia is capable of giving rise to a new apex, but any undamaged superficial area of the meristem either above or between the youngest leaf primordia."

In the limited number of cases of lygus bug injury observed by the writers, the terminal meristem appeared to be completely destroyed. The lateral bud primordia were stimulated into activity and later developed into the growing apex of the stem. Plate 3 shows a longitudinal section through an injured stem tip 4 days after the bugs were removed from the plant. The welldeveloped, uninjured axillary bud at the right has reached the same transverse plane as the terminal growing region which had been destroyed by the feeding of the insects. In normal alfalfa tips (plate 4) the axillary buds first appear as small groups of dark-stained meristematic cells at the axils of the leaf primordia. As these develop, the growth at the apical meristem increases the stem length to such extent that when the lateral buds reach the stage of development shown in plate 3 they are a considerable distance below the terminal growing region. The presence of a lateral bud on the same plane as an injured terminal indicates that it is in the process of being substituted for the normal growing tip. In plate $2, B$, a new terminal apex has been formed at $a$ after the terminal region at $b$ had disintegrated as a result of feeding.

One of the characteristic symptoms accompanying an infestation of lygus bugs on alfalfa stems is the crinkled and misshapen leaves. Inasmuch as the bugs do not normally feed upon the leaves and as attempts to produce these symptoms artificially by confining bugs to the leaves have failed, it appears that these deformities are initiated in the leaf primordia. Disintegrated areas may be seen in plate $2, A$, at $a$, surrounding the punctures made by the bug stylets in the young leaves which enclose the growing tip of the stem. Whenever these damaged areas occur in a young leaf, growth appears to be retarded in the area of the injury and the leaf develops unsymmetrically. This type of growth results in an irregular or deformed leaf. When the young leaves that surround the apical tips of alfalfa stems are examined several days after injury has occurred (plate $2, A$ at $b$ and $B$ at $c$ ), the beginning of such irregularities may be observed.

The histological studies of injury by lygus bugs to the growing points of alfalfa plants make it apparent that definite, measurable decreases in growth and in yield of forage should occur. To test this theory under field conditions would be difficult, if not impossible, because of the many complex factors involved. It was therefore considered desirable to conduct experimental studies under greenhouse conditions where both insects and plants could be subjected to some degree of control. 
GREENHOUSE STUDIES ON THE EFFECTS OF LYGUS BUG INJURIES UPON THE GROWTH OF ALFALFA PLANTS

At the beginning of these studies it was recognized that success in measuring the effects of injury by an insect species on the growth increment of a plant depended upon the degree to which the environmental conditions and the genetic constitution of both the plant and the insects were controlled without greatly changing the growth characteristics of the plant. Special effort, therefore, was made to control growing conditions by selecting plants which showed similarity in native vigor of growth; by growing plants in water cultures with controlled nutrient solutions; and by confining the bugs within the type of cage that would influence to the least possible degree the growth rate of the alfalfa plants.

Experimental Methods.-The plants used in these experiments were started from selected common alfalfa seed. The seeds were sprouted and grown in sand culture until they reached an average height of about 3 inches. The young plants were then transferred to tanks containing water culture solution. The cultural methods were adapted from those used by Hoagland and Arnon (1938).

Shull (1933), Sorenson (1939), and others who have made studies on the life history of Lygus hesperus and L. elisus have reported difficulty in maintaining populations under artificial conditions. Attempts made by the present writers to build up a population in the laboratory failed to supply sufficient insects for the greenhouse studies; therefore the bugs used in these studies were collected from alfalfa fields with an insect net, and transferred by means of an aspirator.

It was recognized that the growth rate of a plant may be greatly influenced by the type of cage needed to confine small insects. For this reason special attempts were made to minimize and to measure the influence of the cage upon the plant growth rate.

Cages were constructed of a cellophane which was permeable to moisture. They were $1 \frac{1}{2}$ feet high and somewhat conical in shape. The smaller end was glued to the metal ring of a fruit jar lid and placed over the cork used to support the plant in the tank. Air was forced into each cage in order to increase ventilation and circulation so that excessively high temperatures might be avoided. The air was supplied from the laboratory air-pressure system, and led from the outlet to the cages through rubber tubing. In order to maintain uniform pressure, and to equalize the air to the various cages, a glass tube having a small terminal diameter was connected to the end of each rubber tube and inserted through a perforated cork fixed in the wall of the cage. A thermometer was placed in one of the cages in order to check the temperature at various times of the day.

At the close of the sixth growth period these cages were discarded because it appeared that the size of the cage near the base was of insufficient diameter to permit adequate air circulation at the crown of the plant. This defect had resulted in the condensation of moisture at the base of the cage, and the development of mold on some of the largest and apparently most healthy plants. This factor was thought to be responsible for the early death of some of the 
plants. New cages, $11 \times 9$ inches and 2 feet high, were constructed. These were of sufficient size at the base to cover four plants. The frames were made of wood and were covered, except at the base, with transparent, moisturepermeable cellophane. A strip of cotton was glued around the bottom of each cage to prevent the bugs from crawling under the edge. Air was forced into each cage, as it had been in the others, but the air flow was increased to allow for the increased volume of the new cages. These were used during the seventh and eighth growth periods of experiment $\mathrm{A}$, and during the sixth and eighth periods of experiment $B$.

Even though a continuous air stream was introduced into these cages, the changes in environmental conditions, caused by enclosure, were sufficient to reduce materially the growth rate of the caged plants. A few plants in experiment A, which were not eaged until 131 days after they had been placed in tanks, grew from six to nine times as rapidly as those which had been caged during the entire period. The weights of plant tops taken at each cutting after the plants were 131 days old showed that uncaged plants had produced two to three times as much growth as those caged. Weights of uncaged plant tops are not included in the tables of this paper. The controls refer to caged plants which were free from bugs.

The reduction in growth rate caused by the cages did not appear to be due to any one factor. The plants enclosed unquestionably were shaded somewhat by the cages themselves, as the cellophane cast a definite shadow ; however, the majority of the uncaged plants were also partially shaded by the cages of surrounding plants. Another factor which may have contributed to the reduction in growth was the constricting effect of the base of the cage. An attempt to eliminate this factor by increasing the size of the cages failed to increase the growth increment of the plants. A third factor which may have retarded growth within the cages was the quantity of air reaching the plant. It is possible that insufficient air was supplied to the plant to permit normal exchange of gases at the leaf surfaces. Plant physiologists have shown that the amount of carbon dioxide may be the limiting factor in plant growth. Meyer and Anderson (1939) state that "Under natural conditions during the summer months in temperate regions the carbon dioxide concentration of the atmosphere is most frequently the limiting factor in photosynthesis for all photosynthetic tissues which are well exposed to light." No ready explanation is available of the limitation in growth of these alfalfa plants as a result of enclosure.

Experiment A.-In experiment A, 96 alfalfa plants were selected on the basis of uniformity of size, and placed in the tanks. These plants were permitted to grow for 60 days; at the end of that period they were rearranged so that the largest plants were placed in tank $\mathrm{A}$ and the smallest in tank $\mathrm{H}$. Case histories were kept of each plant through nine growth periods. At the close of each period the plant stems were cut $2 \frac{1}{2}$ inches above the crown, weighed, and placed in sacks. They were then dried at $60^{\circ} \mathrm{C}$ for 24 hours, after which time they were stored at room temperatures until their weight became constant. The dry weight was then recorded.

In the first three growth periods the plants were left unexposed to insects so that they might become established. However, in each tank all plants, with 
the exception of two, were caged during the second and third periods. The fourth, sixth, seventh, and eighth periods were used to determine the influence of various numbers of bugs on each plant; during the fifth and ninth periods the plants were permitted to develop without injury in order to ascertain the influence of feeding, by the various bug concentrations, upon the following growth period. By the close of the ninth period some of the plants had died. It was also observed that differences in growth increment, due to the treatment the plant previously had received, were gaining magnitude; therefore, it was decided to discontinue the case histories.

Six treatments were made in each of the fourth, sixth, seventh, and eighth cuttings. During every growth period, each treatment was replicated twice

TABLE 1

Mean Daily Dry-Weight Growth Increment of Plants during the First 111 Days IN Experiment A*

\begin{tabular}{|c|c|c|c|c|c|c|c|c|c|c|}
\hline \multirow{2}{*}{ Cutting } & \multirow{2}{*}{$\begin{array}{l}\text { Age } \\
\text { of plant, } \\
\text { days }\end{array}$} & \multicolumn{8}{|c|}{$\begin{array}{l}\text { Mean daily growth increment, in milligrams, } \\
\text { according to tank number }\end{array}$} & \multirow{2}{*}{$\begin{array}{c}\text { Average } \\
\text { daily } \\
\text { growth } \\
\text { increments }\end{array}$} \\
\hline & & 1 & 2 & 3 & 4 & 5 & 6 & 7 & 8 & \\
\hline $\begin{array}{l}\text { First........... } \\
\text { Second } \ldots \ldots \ldots \ldots \ldots \\
\text { Third } \ldots \ldots \ldots \ldots \ldots \ldots\end{array}$ & $\begin{array}{r}73 \\
97 \\
111\end{array}$ & $\begin{array}{r}10.9 \\
40.0 \\
120.6\end{array}$ & $\begin{array}{r}7.5 \\
29.8 \\
96.5\end{array}$ & $\begin{array}{r}12.2 \\
37.4 \\
110.0\end{array}$ & $\begin{array}{l}13.3 \\
33.8 \\
89.8\end{array}$ & $\begin{array}{r}8.8 \\
16.1 \\
128.0\end{array}$ & $\begin{array}{l}11.7 \\
33.0 \\
98.7\end{array}$ & $\begin{array}{r}7.9 \\
24.7 \\
93.3\end{array}$ & $\begin{array}{r}5.8 \\
26.6 \\
91.1\end{array}$ & $\begin{array}{r}9.7 \\
30.2 \\
103.5\end{array}$ \\
\hline $\begin{array}{l}\text { Average growth in- } \\
\text { crement per tank }\end{array}$ & & 57.2 & 44.6 & 53.2 & 45.6 & 50.9 & 47.8 & 41.9 & 41.2 & $\ldots$ \\
\hline
\end{tabular}

* Each mean based on 12 plants in each tank. No significant differences.

in each of the 8 tanks. Because of the difficulty in determining the exact number of bugs alive in each cage, no attempt was made to maintain the original population throughout the experiment; no additional bugs were introduced after the original infestation.

Experiment B.-In experiment B, 108 plants were placed in 9 tanks and cultured as those of experiment A. During the first 42 days of growth, which comprised two growth periods, no cages or bugs were placed on the plants. During the third and fourth periods, single plants were caged and the treatments were replicated twice in each tank and randomized on a tank basis. Cages sufficiently large to cover four plants were used for the sixth and eighth periods, and only three treatments were made in each tank. The treatments were then randomized among the 9 tanks. Cages were removed from the plants for the fifth, seventh, and ninth periods in order to ascertain the influence of injury received by the plants as a result of bug feeding, on the subsequent growth of the plants.

Results.-The results were compiled on the basis of the daily growth increment of each plant. This was obtained by dividing the weight of each plant when harvested, at the end of the period of growth, by the number of days in the period. This will be referred to as growth rate, or increment, in the tables and the discussion.

A steady increase in growth increment was apparent in the 111 days that were allowed for the plants to become established in experiment A (table 1). 
Analysis of the weight samples taken three times during this period shows that the growth rate of each plant within a single tank was proportional to the other plants in the same tank, and that the plants of one tank increased in growth increment in proportion to the plants of the other tanks.

The symptoms resulting from the injury caused by the lygus bugs vary according to the severity of the damage. The injured plants were darker in color, the leaves more ovate, crinkled, and misshapen than the leaves on healthy plants. In cases of extreme injury the leaves were very small, the internodes short, and the stems thin and crooked.

The growth rate during the fourth growth period was greatly reduced when lygus bugs were confined on a plant. Table 2 shows the mean growth increment

TABLE 2

Mean Daily Growth Increments of Plants Infested with Lygus Bugs in the Fourth Growth Period of Experiment A*

\begin{tabular}{|c|c|c|c|c|c|}
\hline \multirow{2}{*}{$\begin{array}{l}\text { Number of bugs } \\
\text { on each plant }\end{array}$} & \multicolumn{2}{|c|}{$\begin{array}{l}\text { Mean daily growth } \\
\text { increment, } \\
\text { in milligrams } †\end{array}$} & \multicolumn{2}{|c|}{$\begin{array}{c}\text { Per cent growth } \\
\text { increments as compared } \\
\text { with check plants }\end{array}$} & \multirow{2}{*}{$\begin{array}{c}\text { Per cent } \\
\text { moisture } \\
\text { content } \\
\text { of } \\
\text { plants }\end{array}$} \\
\hline & $\begin{array}{l}\text { Fresh } \\
\text { weight }\end{array}$ & $\begin{array}{c}\text { Dry } \\
\text { weight }\end{array}$ & $\begin{array}{c}\text { Fresh } \\
\text { weight }\end{array}$ & $\begin{array}{c}\text { Dry } \\
\text { weight }\end{array}$ & \\
\hline Control.. & 696 & 100.4 & 100.0 & 100.0 & 85 \\
\hline $2 \ldots \ldots$ & 260 & 45.1 & 37.4 & 44.9 & 82 \\
\hline $4 \ldots \ldots \ldots$ & 298 & 44.7 & 44.4 & 44.5 & 85 \\
\hline $8 \ldots \ldots \ldots \ldots \ldots \ldots$ & 198 & 33.7 & 28.7 & 33.5 . & 83 \\
\hline $16 \ldots \ldots \ldots \ldots \ldots \ldots$ & 116 & 16.8 & 16.6 & 16.7 & 85 \\
\hline
\end{tabular}

* Each mean based on 16 plants.

$t$ Least difference necessary for significance in weight at the 5 per cent level: fresh weight, 161.89; and dry weight, 15.39. At the 1 per cent level: fresh weight, 218.42; and dry weight, 20.77 .

of the 16 plants in the check and with each of four populations of bugs. Analysis of these data indicated that differences in treatments, when expressed either as green, or as dry weight, were highly significant. The least significant difference between means based on fresh weight was 161.89 milligrams, and on dry weight, 15.39 .

In general, the growth of the plants was more rapid when there were fewer bugs feeding on them. When 2 to 4 bugs fed on plants of this size (fourth period of experiment $A$ ) the growth rate was reduced to about 45 per cent of that of the check plants; and when 8 and 16 bugs were introduced, the growth rate was reduced to about one third and one sixth, respectively, as compared with untreated plants. There was no difference in the growth increment of plants exposed to the feeding of 2 as compared with that of 4 bugs (table 2 ). The mean differences in fresh weights of plants having 2 and 16 or 8 and 16 bugs on each plant were not of sufficient magnitude to be significant at the 5 per cent level, whereas the dry-weight differences were significant. The moisture content of the plants, however, varied no more than 3 per cent between any of the treatments, and plants subjected to the feeding of 16 bugs had as high percentage of moisture as the check plants. Differences in weights obtained between infested and uninfested plants are therefore not a direct result of the removal of the plant juices by these sucking insects, but are 
measurements of the top growth produced by the alfalfa plants. The data indicate that the primary cause of reduced growth is not a disturbance of water balance in the plant caused by removal of water through the feeding of the insects.

The results from the sixth growth period are shown in table 3 . The decrease in growth increment, as a result of infestation, is not of the same magnitude

TABLE 3

Mean Daily Growth Increments of Plants Infested with Lygus Bugs in the Sixth Growth Period of Experiment A*

\begin{tabular}{|c|c|c|c|c|c|}
\hline \multirow{2}{*}{$\begin{array}{l}\text { Number of bugs } \\
\text { on each plant }\end{array}$} & \multicolumn{2}{|c|}{$\begin{array}{l}\text { Mean daily growth } \\
\text { increment } \\
\text { in milligrams } †\end{array}$} & \multicolumn{2}{|c|}{$\begin{array}{c}\text { Per cent growth } \\
\text { increments as compared } \\
\text { with control plants }\end{array}$} & \multirow{2}{*}{$\begin{array}{c}\text { Per cent } \\
\text { moisture } \\
\text { content } \\
\text { of } \\
\text { plants }\end{array}$} \\
\hline & $\begin{array}{c}\text { Fresh } \\
\text { weight }\end{array}$ & $\begin{array}{c}\text { Dry } \\
\text { weight }\end{array}$ & $\begin{array}{c}\text { Fresh } \\
\text { weight }\end{array}$ & $\begin{array}{c}\text { Dry } \\
\text { weight }\end{array}$ & \\
\hline Control. & 735 & 99.5 & 100.0 & 100.0 & 86 \\
\hline $2 \ldots \ldots$ & 711 & 109.9 & 96.7 & 110.4 & 84 \\
\hline $4 \ldots$ & 686 & 101.0 & 93.2 & 101.8 & 85 \\
\hline $8 \ldots$ & 508 & 84.0 & 69.1 & 84.3 & 83 \\
\hline $16 \ldots$ & 423 & 74.0 & 57.5 & 74.3 & 82 \\
\hline
\end{tabular}

* Each mean based on 16 plants.

t Least difference necessary for significance in weight at the 5 per cent level: fresh weight, 221.45; dry weight, no significant differences.

\section{TABLE 4}

Mean Daily Growth Increments of Plants Infested with Lygus Bugs in the Seventh Growth Period of Experiment A*

\begin{tabular}{|c|c|c|c|c|c|}
\hline \multirow{2}{*}{$\begin{array}{l}\text { Number of bugs } \\
\text { on each plant }\end{array}$} & \multicolumn{2}{|c|}{$\begin{array}{l}\text { Mean daily growth } \\
\text { increment } \\
\text { in milligrams } \dagger\end{array}$} & \multicolumn{2}{|c|}{$\begin{array}{l}\text { Per cent growth } \\
\text { increments as compared } \\
\text { with check plants }\end{array}$} & \multirow{2}{*}{$\begin{array}{c}\text { Per cent } \\
\text { moisture } \\
\text { content } \\
\text { of } \\
\text { plants }\end{array}$} \\
\hline & $\begin{array}{l}\text { Fresh } \\
\text { weight }\end{array}$ & $\begin{array}{c}\text { Dry } \\
\text { weight }\end{array}$ & $\begin{array}{l}\text { Fresh } \\
\text { weight }\end{array}$ & $\begin{array}{c}\text { Dry } \\
\text { weight }\end{array}$ & \\
\hline Control.. & 430 & 70 & 100.0 & 100.0 & 83.7 \\
\hline $2 \ldots \ldots \ldots \ldots$ & 380 & 64 & 88.3 & 91.4 & 83.2 \\
\hline $4 \ldots \ldots \ldots \ldots \ldots$ & 338 & 56 & 78.6 & 80.0 & 83.4 \\
\hline $8 \ldots \ldots \ldots \ldots \ldots$ & 270 & 52 & 62.6 & 74.3 & 80.7 \\
\hline $16 \ldots \ldots \ldots \ldots \ldots \ldots$ & 310 & 57 & 72.1 & 81.4 & 81.6 \\
\hline
\end{tabular}

* Each mean based on 16 plants.

$\dagger$ No significant differences.

as was shown during the fourth period. The variations in weights within treatments also were greater. As a result, an analysis of the fresh weights showed significant differences between bug populations at the 5 per cent level, whereas the results of dry weights were under this level for significance. There was, nevertheless, considerable reduction in growth increment when 8 and 16 bugs were confined with the plants. The amount of moisture in the plants upon which 8 or 16 bugs were confined was 4 to 5 per cent less than the checks. This difference is small and not statistically significant; therefore, it may be attributed to experimental error, although the point should not be entirely ignored, for it occurs also in the seventh period of experiment A (table 4) and the third and fourth periods of experiment B (tables 7 and 8, respectively). 
The results showing growth increment of the seventh period (table 4) indicate a reduced rate of growth as the number of bugs was increased, except that when 16 bugs were introduced to each plant the growth rates of each plant averaged slightly more than with plants subjected to the feeding of 8 bugs. These differences between treatments, however, because of the degree

TABLE 5

Mean Daily Growth Increments of Plants Infested with Lygus Bugs in the Eighth Growth Period of Experiment A*

\begin{tabular}{|c|c|c|c|c|c|}
\hline \multirow{2}{*}{$\begin{array}{l}\text { Number of bugs } \\
\text { on each plant }\end{array}$} & \multicolumn{2}{|c|}{$\begin{array}{l}\text { Mean daily growth } \\
\text { increment } \\
\text { in milligrams } †\end{array}$} & \multicolumn{2}{|c|}{$\begin{array}{l}\text { Per cent growth } \\
\text { increments as compared } \\
\text { with check plants }\end{array}$} & \multirow{2}{*}{$\begin{array}{c}\text { Per cent } \\
\text { moisture } \\
\text { content } \\
\text { of } \\
\text { plants }\end{array}$} \\
\hline & $\begin{array}{c}\text { Fresh } \\
\text { weight }\end{array}$ & $\begin{array}{c}\text { Dry } \\
\text { weight }\end{array}$ & $\begin{array}{c}\text { Fresh } \\
\text { weight }\end{array}$ & $\begin{array}{c}\text { Dry } \\
\text { weight }\end{array}$ & \\
\hline Control........... & 381 & 76 & 100.0 & 100.0 & 80.0 \\
\hline $2 \ldots$ & 373 & 71 & 97.9 & 93.4 & 80.9 \\
\hline $4 \ldots$ & 427 & 75 & 112.0 & 98.7 & 82.4 \\
\hline $8 \ldots$ & . 383 & 64 & 100.4 & 84.2 & 83.2 \\
\hline $16 \ldots .$. & 310 & 62 & 81.4 & 81.5 & 80.0 \\
\hline
\end{tabular}

* Each mean based on 16 plants.

† No significant differences.

TABLE 6

Age of Plants, Intervals between Cutpings and Infestation, and Length of Feeding Periods as Reflected in Percentage Reduction of Plant Growth in Experiment A

\begin{tabular}{|c|c|c|c|c|c|c|c|c|c|c|}
\hline \multirow{2}{*}{$\begin{array}{c}\text { Age of } \\
\text { plants } \\
\text { in days }\end{array}$} & \multirow{2}{*}{$\begin{array}{c}\text { Days } \\
\text { between } \\
\text { cutting and } \\
\text { bug } \\
\text { infestation }\end{array}$} & \multirow{2}{*}{$\begin{array}{l}\text { Number } \\
\text { of days } \\
\text { plants were } \\
\text { subjected } \\
\text { to injury }\end{array}$} & \multicolumn{2}{|c|}{2 bugs } & \multicolumn{2}{|c|}{4 bugs } & \multicolumn{2}{|c|}{8 bugs } & \multicolumn{2}{|c|}{16 bugs } \\
\hline & & & $\begin{array}{c}\text { Fresh } \\
\text { weight }\end{array}$ & $\underset{\text { Dryght }}{\text { weight }}$ & $\begin{array}{c}\text { Fresh } \\
\text { weight }\end{array}$ & $\begin{array}{c}\text { Dry } \\
\text { weight }\end{array}$ & $\begin{array}{c}\text { Fresh } \\
\text { weight }\end{array}$ & $\begin{array}{c}\text { Dry } \\
\text { weight }\end{array}$ & $\begin{array}{c}\text { Fresh } \\
\text { weight }\end{array}$ & $\begin{array}{c}\text { Dry } \\
\text { weight }\end{array}$ \\
\hline 135 & 3 & 20 & 62.6 & 55.1 & 55.6 & 55.5 & 71.3 & 66.5 & 83.4 & 83.3 \\
\hline 177 & 13 & 8 & 3.3 & $10.4^{*}$ & 6.8 & $1.8^{*}$ & 30.9 & 15.7 & 42.5 & 25.7 \\
\hline 203 & 12 & 14 & 11.7 & 8.6 & 21.4 & 20.0 & 37.4 & 25.7 & 27.9 & 18.6 \\
\hline 238 & 8 & 27 & 2.1 & 6.6 & $12.0^{*}$ & 1.3 & $0.4^{*}$ & 15.8 & 18.6 & 18.5 \\
\hline
\end{tabular}

* Increase.

of variation within each treatment are not of sufficient magnitude to be significant at the 5 per cent level. A small decrease in water content was indicated in the plants that produced the least growth.

The differences between treatments during the eighth growth period (table 5) were not sufficient to show significance when fewer than 8 bugs were introduced to the plants, but those exposed to 16 bugs showed a growth which was only 81 per cent of that of the check plants.

A comparison of the effect of lygus-bug feeding on plant growth at several intervals of development (table 6 ) indicates that more bugs were required to retard substantially the growth rate when the plants were young than when they were older and had acquired a larger root system. The first introduction 
of bugs was made only 3 days after the plants were cut; later introductions were made after 8 and 13 days had expired. The length of time in which the bugs were on the plants was less, in the last period, when their influence was of lower magnitude, than in the first period. This suggests that injury to the plant, immediately after cutting, more seriously reduced plant growth than after the plant stems had become well started in development.

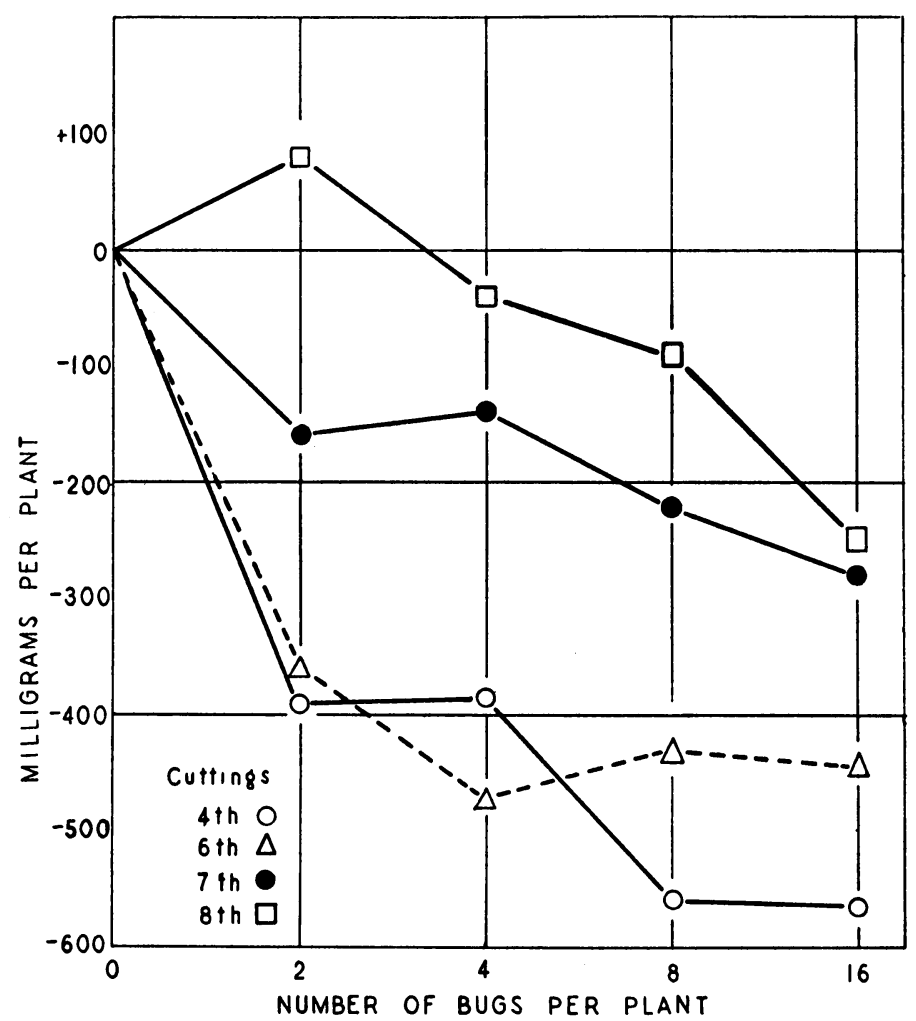

Fig. 1.-Reduction in daily fresh-weight growth increment in experiment $A$ as a result of feeding by varying numbers of lygus bugs. The daily growth increments of each plant of the previous period were subtracted from those of the period shown, and the resulting means of each bug population were subtracted from those of the check plants. Each value represents the mean of 16 plants.

The decrease in growth rate caused by an increase in bug population, is more consistent when the results from each cutting are compared with those of the previous cutting (figure 1). These graphs also emphasize the lessened influence of corresponding populations of bugs as the plants increased in age.

The results from the second group of plants (experiment B) show a decrease in growth increment as the number of bugs is increased (much as those of the first group) ; however, the magnitude of the differences was not so great in the third and fourth periods as it was in the fourth period of experiment $A$. During the sixth to eighth periods the reduction of growth was greater when 2 or 4 bugs were introduced in the second group of plants than in the first 
group. During the third growth period of experiment B (table 7) there were no significant differences in plant growth as a result of feeding by different bug populations, when measured by either dry or fresh weight; however, mean weights of plants upon which 3 to 9 bugs were fed were less than the untreated plants.

\section{TABLE 7}

Mean Daily Growth Increments of Plants Infested with Lygus Bugs in the Third Growth Period of Experiment B*

\begin{tabular}{|c|c|c|c|c|c|}
\hline \multirow{2}{*}{$\begin{array}{l}\text { Number of bugs } \\
\text { on each plant }\end{array}$} & \multicolumn{2}{|c|}{$\begin{array}{l}\text { Mean daily growth } \\
\text { increment } \\
\text { in milligrams } †\end{array}$} & \multicolumn{2}{|c|}{$\begin{array}{c}\text { Per cent growth } \\
\text { increments as compared } \\
\text { with check plants }\end{array}$} & \multirow{2}{*}{$\begin{array}{c}\text { Per cent } \\
\text { moisture } \\
\text { content } \\
\text { of } \\
\text { plants }\end{array}$} \\
\hline & $\begin{array}{l}\text { Fresh } \\
\text { weight }\end{array}$ & $\begin{array}{c}\text { Dry } \\
\text { weight }\end{array}$ & $\begin{array}{c}\text { Fresh } \\
\text { weight }\end{array}$ & $\begin{array}{c}\text { Dry } \\
\text { weight }\end{array}$ & \\
\hline Control.............. & 521 & 71 & 100.0 & 100.0 & 86.3 \\
\hline $1 \ldots \ldots \ldots \ldots \ldots \ldots \ldots \ldots$ & 532 & 72 & 102.1 & 101.4 & 86.4 \\
\hline $3 \ldots \ldots \ldots \ldots \ldots \ldots \ldots \ldots$ & 392 & 62 & 75.2 & 87.3 & 84.2 \\
\hline $6 \ldots$ & 431 & 67 & 82.7 & 94.3 & 84.4 \\
\hline $9 \ldots \ldots \ldots$ & 344 & 67 & 66.0 & 94.3 & 80.5 \\
\hline
\end{tabular}

* Each mean based on 18 plants.

$\uparrow$ No significant differences.

TABLE 8

Mean Daily Growth Increments of Plants Infested with Lygus Bugs in the Fourth Growth Period of Experiment B*

\begin{tabular}{|c|c|c|c|c|c|}
\hline \multirow{2}{*}{$\begin{array}{l}\text { Number of bugs } \\
\text { on each plant }\end{array}$} & \multicolumn{2}{|c|}{$\begin{array}{l}\text { Mean daily growth } \\
\text { increment } \\
\text { in milligrams } \dagger\end{array}$} & \multicolumn{2}{|c|}{$\begin{array}{l}\text { Per cent growth } \\
\text { increments as compared } \\
\text { with check plants }\end{array}$} & \multirow{2}{*}{$\begin{array}{c}\text { Per cent } \\
\text { moisture } \\
\text { content } \\
\text { of } \\
\text { plants }\end{array}$} \\
\hline & $\begin{array}{c}\text { Fresh } \\
\text { weight }\end{array}$ & $\begin{array}{c}\text { Dry } \\
\text { weight }\end{array}$ & $\begin{array}{l}\text { Fresh } \\
\text { weight }\end{array}$ & $\begin{array}{c}\text { Dry } \\
\text { weight }\end{array}$ & \\
\hline Control............. & 362 & 53 & 100.0 & 100.0 & 85.3 \\
\hline $1 \ldots$ & 299 & 45 & 82.8 & 84.9 & 84.9 \\
\hline $3 \ldots$ & 210 & 42 & 58.0 & 79.2 & 80.0 \\
\hline $6 \ldots$ & 143 & 27 & 39.5 & 51.0 & 81.1 \\
\hline $9 \ldots \ldots \ldots \ldots$ & 153 & 33 & 42.2 & 62.2 & 78.4 \\
\hline
\end{tabular}

* Each mean based on 18 plants.

† Least difference necessary for significance in weight at the 5 per cent level: fresh weight, 148.09; and dry weight, 23.52. At the 1 per cent level: fresh weight 199.42; and dry weight, no significant differences.

Both the fresh and the dry weights taken from the fourth period (table 8) of experiment $B$ indicate that when alfalfa plants were exposed to the feeding of 2 to 16 bugs the growth rate was significantly retarded. A difference of more than 148.09 milligrams fresh weight and 23.5 milligrams dry weight between any treatments is significant. Three or more bugs, therefore, reduced growth significantly over the check, and 6 and 9 over those plants upon which 1 bug was feeding (table 8 ). There was a variation of about 7 per cent in the moisture content between treatments, and plants fed upon by 9 bugs had the lowest percentage of water.

The results of the sixth and eighth growth periods also correspond to those of the other periods in reduction of growth increment when plants were ex- 
posed to the feeding activities of the insects. During the sixth period, treatment was made 4 days after cutting, and 4 bugs reduced growth to less than 70 per cent as much as that of the check plants (table 9). Analysis of the diry-weight increments indicated that the differences in means could not be entirely attributed to experimental error. At the eighth cutting the growth increment of plants exposed to 2 bugs was 63 and 74 per cent in fresh and dry weight, respectively - as much as in untreated plants.

It was not possible to count the number of living bugs present on a plant without removing the cage; therefore, the number which survived was not

TABLE 9

Mean Daily Growth Increments of Plants Infested with Lygus Bugs in the Sixth and Eighth Growth Periods of Experiment B*

\begin{tabular}{|c|c|c|c|c|c|}
\hline \multirow{2}{*}{$\begin{array}{l}\text { Number of bugs } \\
\text { on each plant }\end{array}$} & \multicolumn{2}{|c|}{$\begin{array}{l}\text { Mean daily growth } \\
\text { increment } \\
\text { in milligrams }\end{array}$} & \multicolumn{2}{|c|}{$\begin{array}{c}\text { Per cent growth } \\
\text { increments as compared } \\
\text { with check plants }\end{array}$} & \multirow{2}{*}{$\begin{array}{c}\text { Per cent } \\
\text { moisture } \\
\text { content } \\
\text { of } \\
\text { plants }\end{array}$} \\
\hline & $\begin{array}{c}\text { Fresh } \\
\text { weight }\end{array}$ & $\begin{array}{c}\text { Dry } \\
\text { weight }\end{array}$ & $\begin{array}{c}\text { Fresh } \\
\text { weight }\end{array}$ & $\begin{array}{c}\text { Dry } \\
\text { weight }\end{array}$ & \\
\hline \multicolumn{6}{|c|}{ Sixth period } \\
\hline $\begin{array}{l}\text { Control................ } \\
4 \ldots \ldots \ldots \ldots \ldots \ldots \ldots\end{array}$ & $\begin{array}{l}240 \\
160\end{array}$ & $\begin{array}{l}44.7 \dagger \\
29.0 \dagger\end{array}$ & $\begin{array}{r}100.0 \\
66.7\end{array}$ & $\begin{array}{r}100.0 \\
68.3\end{array}$ & $\begin{array}{l}82.9 \\
82.5\end{array}$ \\
\hline \multicolumn{6}{|c|}{ Eighth period $\ddagger$} \\
\hline $\begin{array}{l}\text { Control.......... } \\
2 \ldots \ldots \ldots \ldots \ldots \ldots\end{array}$ & $\begin{array}{l}190 \\
120\end{array}$ & $\begin{array}{l}28.0 \\
20.0\end{array}$ & $\begin{array}{r}100.0 \\
63.1\end{array}$ & $\begin{array}{r}100.0 \\
74.0\end{array}$ & $\begin{array}{l}85.7 \\
83.3\end{array}$ \\
\hline
\end{tabular}

determined until the alfalfa was cut. No correlation could be made between growth and the length of time the insects survived on the plants; however, a relationship between the number of bugs surviving at the close of each period and the growth of the plants can be shown. Tables 10 and 11 show the dryweight daily growth increment of all plants over which individual cages were placed, and the number of living bugs found at the end of the period.

It appears from a study of these tables that the average weights of plants supporting the largest number of living lygus bugs, at the end of each treatment, was greater in 11 of the 20 treatments than the weights of plants on which the bug mortality was 100 per cent. At first glance it seems paradoxical that the results should indicate a reduction in growth rate when the initial bug population was increased and yet show less decrease in growth rate of plants which supported the largest percentage of the population throughout the entire growth period. Observations have shown that these lygus bugs feed largely on the meristematic tissue of the growing alfalfa stem. It is possible that 2 or more bugs continually feeding on the growing tips of an alfalfa plant may make the plant less suitable as food unless the plant is able to produce 
TABLE 10

Mean Daily Dry-Weight Growth Increment of Plants ARRanged According to Number of Lygus Bugs Living at Close of PERIOd IN Experinent A

\begin{tabular}{|c|c|c|c|c|}
\hline \multirow{2}{*}{$\begin{array}{c}\text { Number of bugs introduced } \\
\text { per plant }\end{array}$} & \multirow{2}{*}{$\begin{array}{l}\text { Number of } \\
\text { bugs living } \\
\text { at end } \\
\text { of period }\end{array}$} & \multicolumn{3}{|c|}{$\begin{array}{l}\text { Increments of growth in three periods, } \\
\text { expressed in milligrams }\end{array}$} \\
\hline & & $\begin{array}{l}\text { Fourth } \\
\text { period }\end{array}$ & $\begin{array}{l}\text { Sixth } \\
\text { period }\end{array}$ & $\begin{array}{l}\text { Seventh } \\
\text { period }\end{array}$ \\
\hline $2 \ldots \ldots$ & $\begin{array}{l}0 \\
1 \\
2\end{array}$ & $\begin{array}{l}56 \\
43 \\
33\end{array}$ & $\begin{array}{c}48^{*} \\
86 \\
133\end{array}$ & $\begin{array}{r}75 \\
60 \\
. .\end{array}$ \\
\hline $4 \ldots \ldots \ldots \ldots \ldots \ldots \ldots \ldots$ & $\begin{array}{l}0 \\
1 \\
2-4\end{array}$ & $\begin{array}{l}45^{*} \\
42 \\
55^{*}\end{array}$ & $\begin{array}{c}125^{*} \\
97 \\
86\end{array}$ & $\begin{array}{l}44 \\
59 \\
\ldots\end{array}$ \\
\hline $8 \ldots \ldots \ldots \ldots \ldots \ldots \ldots \ldots$ & $\begin{array}{l}0 \\
1-3 \\
4-8\end{array}$ & $\begin{array}{l}40^{*} \\
35 \\
40\end{array}$ & $\begin{array}{l}65^{*} \\
79 \\
89\end{array}$ & $\begin{array}{l}\ddot{4} \\
37\end{array}$ \\
\hline $16 \ldots$ & $\begin{array}{l}0 \\
1-3 \\
4-8 \\
9-16\end{array}$ & $\begin{array}{l}40^{*} \\
15 \\
12 \\
24\end{array}$ & $\begin{array}{c}47^{*} \\
73 \\
46^{*} \\
101\end{array}$ & $\begin{array}{r}35 \\
+\quad 43 \\
69 \\
81\end{array}$ \\
\hline
\end{tabular}

* Means taken from only 1 to 3 plants.

TABLE 11

Mean Daily Dry-Weight Growth Increment of Plants ARranged According to Number of Lygus Bugs Living at Close of Period in Experiment B

\begin{tabular}{|c|c|c|c|}
\hline \multirow{2}{*}{$\begin{array}{l}\text { Number of bugs introduced } \\
\text { per plant }\end{array}$} & \multirow{2}{*}{$\begin{array}{c}\text { Number of bugs } \\
\text { living at } \\
\text { end of period }\end{array}$} & \multicolumn{2}{|c|}{$\begin{array}{l}\text { Increments of growth in two } \\
\text { periods, expressed in milligrams }\end{array}$} \\
\hline & & Third period & Fourth period \\
\hline \multirow[t]{3}{*}{1.} & 0 & 43 & 46 \\
\hline & 1 & 65 & 44 \\
\hline & 0 & 54 & 43 \\
\hline \multirow[t]{3}{*}{3 . } & 1 & 57 & 48 \\
\hline & $2-3$ & 71 & $25^{*}$ \\
\hline & 0 & 49 & 29 \\
\hline \multirow[t]{3}{*}{6.} & $1-3$ & 67 & 26 \\
\hline & $4-6$ & 80 & 40 \\
\hline & 0 & 75 & 37 \\
\hline \multirow[t]{2}{*}{$9 \ldots \ldots \ldots \ldots$} & $1-3$ & 56 & 35 \\
\hline & 4-9 & 81 & $32^{*}$ \\
\hline
\end{tabular}

* Means taken from only 1 to 3 plants. 
TABLE 12

Mean Daily Growth Increments of Uninfested Plants in the Fifth Period of Experiment A*

\begin{tabular}{|c|c|c|c|}
\hline \multirow{2}{*}{$\begin{array}{l}\text { Number of bugs on plants } \\
\text { in previous period }\end{array}$} & \multicolumn{2}{|c|}{$\begin{array}{c}\text { Mean daily growth increment } \\
\text { of uninfested plants, } \\
\text { expressed in milligrams } \dagger\end{array}$} & \multirow{2}{*}{$\begin{array}{l}\text { Per cent } \\
\text { moisture } \\
\text { content } \\
\text { of plants }\end{array}$} \\
\hline & Fresh weight & Dry weight & \\
\hline$\ldots \ldots \ldots \ldots \ldots \ldots \ldots \ldots$ & 1,130 & 131 & 88.4 \\
\hline 2. & 1,410 & 182 & 87.1 \\
\hline $4 \ldots$ & 1,360 & 181 & 86.7 \\
\hline $8 \ldots$ & 1,820 & 249 & 86.3 \\
\hline $16 \ldots$ & 1,430 & 192 & 86.5 \\
\hline
\end{tabular}

* Each mean based on 16 plants.

$\dagger$ No significant differences. Least difference necessary for significance is $104 \mathrm{milli}$ grams.

\section{TABLE 13}

Mean Daily Growth Increments of Uninfested Plants in the Ninth Period of Experiment A*

\begin{tabular}{|c|c|c|c|}
\hline \multirow{2}{*}{$\begin{array}{l}\text { Number of bugs on plants } \\
\text { in previous period }\end{array}$} & \multicolumn{2}{|c|}{$\begin{array}{c}\text { Mean daily growth increment } \\
\text { of uninfested plants, } \\
\text { expressed in milligrams }\end{array}$} & \multirow{2}{*}{$\begin{array}{l}\text { Per cent } \\
\text { moisture } \\
\text { content } \\
\text { of plants }\end{array}$} \\
\hline & Fresh weight & Dry weight & \\
\hline Control $\ldots \ldots \ldots \ldots \ldots \ldots \ldots \ldots$ & 1.343 & 202 & 84.9 \\
\hline$\ldots \ldots \ldots \ldots \ldots \ldots \ldots \ldots \ldots$ & 1,548 & 235 & 84.7 \\
\hline$\ldots \ldots$ & 1.214 & 183 & 85.7 \\
\hline 8. . & 1,188 & 172 & 85.6 \\
\hline 16. & 1,080 & 166 & 84.6 \\
\hline
\end{tabular}

* No statistical analysis was made because several plants were missing in each treatment.

\section{TABLE 14}

Mean Daily Growth Increments of Uninfested Plants in the Fifth Period of Experiment B*

\begin{tabular}{|c|c|c|c|}
\hline \multirow{2}{*}{$\begin{array}{l}\text { Number of bugs on plants } \\
\text { in previous period }\end{array}$} & \multicolumn{2}{|c|}{$\begin{array}{c}\text { Mean daily growth increment } \\
\text { of uninfested plants, } \\
\text { expressed in milligrams }\end{array}$} & \multirow{2}{*}{$\begin{array}{l}\text { Per cent } \\
\text { moisture } \\
\text { content } \\
\text { of plants }\end{array}$} \\
\hline & Fresh weight & Dry weight & \\
\hline Control ............ & 314 & 46.0 & 85.3 \\
\hline $1 \ldots$ & 420 & 61.0 & 85.5 \\
\hline $3 \ldots$ & 466 & 64.0 & 86.2 \\
\hline$\ldots \ldots$ & 376 & 55.2 & 85.4 \\
\hline$\ldots \ldots \ldots$ & 421 & 58.8 & 86.0 \\
\hline
\end{tabular}

* Each mean based on 18 plants.

$\dagger$ No significant differences. 
sufficient new meristematic tissue. Should this be possible, it would suggest one reason why trials made to maintain a population of bugs on a small number of plants in the laboratory have proved unsuccessful.

In order to ascertain the influence of lygus bugs feeding on growth of the succeeding period, the plants were allowed to grow without exposure to insects during the fifth and ninth periods of experiment $A$ and the fifth, seventh, and ninth periods of experiment B (tables 12 to 15). An analysis of the growth increments of these periods indicated significant differences in only the fifth period of experiment $A$ and the seventh period of experiment $B$. These differ-

TABLE 15

Mean Daily Growth Increments of Uninfested Plants in the Seventh and Ninth Periods of Experiment B

\begin{tabular}{|c|c|c|c|}
\hline \multirow{2}{*}{$\begin{array}{l}\text { Number of bugs on plants } \\
\text { in previous period }\end{array}$} & \multicolumn{2}{|c|}{$\begin{array}{l}\text { Mean daily growth increment } \\
\text { of uninfested plants, } \\
\text { expressed in milligrams }\end{array}$} & \multirow{2}{*}{$\begin{array}{l}\text { Per cent } \\
\text { moisture } \\
\text { content } \\
\text { of plants }\end{array}$} \\
\hline & Fresh weight & Dry weight & \\
\hline \multicolumn{4}{|c|}{ Seventh period } \\
\hline $\begin{array}{l}\text { Control........... } \\
4 \ldots \ldots \ldots \ldots \ldots\end{array}$ & $\begin{array}{l}581 \\
501\end{array}$ & $\begin{array}{l}99.0 \\
85.0\end{array}$ & $\begin{array}{l}83.0 \\
83.1\end{array}$ \\
\hline \multicolumn{4}{|c|}{ Ninth period } \\
\hline 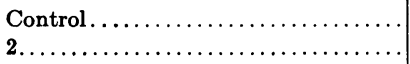 & $\begin{array}{l}650 \\
630\end{array}$ & $\begin{array}{l}36.3 \\
33.4\end{array}$ & $\begin{array}{l}94.4 \\
94.6\end{array}$ \\
\hline
\end{tabular}

ences did not indicate a carryover of bug injury from the previous period, although plants greatly retarded in growth when young, either by bugs or cages, did not equal the growth rate of unaffected plants for several cuttings.

\section{DISCUSSION}

Injury to the tissues of alfalfa plants by lygus bugs appears to cause a local disintegration of cells surrounding the point of feeding. During the vegetative growing period of the stems these areas of injury were usually found to occur at the terminal growing point and lateral bud primordia. The meristematic tissue may be completely destroyed at these points. It is likely that stem growth continues in such cases by the stimulation of uninjured lateral buds to replace the injured growing points. A normal bud has several lateral bud primordia (plate 4), and a possible replacement of any of these for the injured terminal would permit an almost continual vegetative growth despite the large local areas of disintegration. When the plants are in the reproductive phase of growth there is no evidence of such a ready substitution. This suggests an explanation for the consistent injury shown by lygus bugs to seed production and for some of the variations in their influence on the growth rate of alfalfa. At cutting, the terminal bud and most of the lateral buds are removed; this leaves very little meristematic tissue upon which the bugs can feed, and a few 
of them could conceivably retard plant growth more than a large number after the stems have formed new terminal and lateral buds. The unusual degree of growth reduction in the two periods in which bugs were introduced three and four days after cutting (tables 4 and 7 ) may have been due to this factor.

The leaf deformity which is a characteristic symptom of infestation by lygus bugs appears to result from a penetration of the young leaves by the stylets. Carlson (1940, page 805) raises objection to this view because he found that "Damage to young flower buds, which are probably less sensitive to injury than leaf bud primordia, results in immediate and complete deterioration." The sections of buds in the vegetative stage of growth (plate 2) indicate that the lygus bug stylets penetrate through the young leaves which surround the growing regions of the stem. There appears to be only a slight deterioration of tissue surrounding the path of penetration of the stylets, whereas a large area is involved around the point of feeding, which seems to be principally on the flower buds and other growing regions (plates 1 and 2). The larger area of injury at the feeding point suggests that either a toxin was injected by the insects while feeding, which was only local in its effect, or the bugs by "probing around" and removing cell sap, injured large areas. This was followed by secondary pathological disintegration.

The methods and techniques used in the experimental studies permitted a considerable variation in the growth of the plants, which could be attributed to the influence of cages, nutrients, and undefinable causes ; nevertheless, the results as presented in the various tables in this paper show that the injury caused by lygus bugs can be measured in terms of decrease in growth increment. In each of the groups of plants upon which 6 or more bugs were placed there was a substantial decrease in growth over that of the check plants. The populations introduced to the plant in these experiments should not be interpreted in terms of field populations since in five out of the eight growth periods the bugs were on the plants less than half of the period. Only one third of the bugs survived during the entire length of the growth periods, and it is likely that a high percentage of this mortality took place shortly after their introduction, as a result of injury in collecting and handling. On the other hand, the presence of a cage over the plant resulted in a marked decrease in growth, which suggests the possibility that the caged plants may not have been able to recover from injury as readily as the uncaged plants.

Carlson (1940, pages 809 to 811) found that plants continuously infested from the prebud stage to seed harvest time weighed significantly more than uninfested plants, and his photographs well illustrate the difference in growth. He states that "It is not known definitely, however, whether this excess growth results from a failure of the plants to set seed or from a stimulation due to Lygus injury." In the same paper, however, his photographs taken of infested and uninfested plants in the full-bloom stage, indicate that the uninfested plants had produced the greater growth. Although Carlson showed that lygus bug injury resulted in excessive branching and dropping of the flowers, he failed to point out the possibility that the greater weight of the infested plants may have resulted from a longer vegetative growing period. It is well known that the vegetative growth rate of alfalfa decreases as the flowers and seeds 
develop. It is more likely that the inhibition of reproductive growth by the lygus bugs resulted in a continuation of the vegetative growth over a longer period rather than in any stimulatory effects produced by them.

\section{SUMMARY}

Histological sections of alfalfa tips from stems 2 to 4 inches high, taken 2 to 4 days after being artificially infested with lygus bugs, showed large areas of cell disintegration of the terminal and lateral bud primordia.

Longitudinal sections of uninjured alfalfa tips 2 to 4 inches high showed lateral bud primordia in progressive stages of development at successively lower transverse planes than the terminal meristem, whereas infested alfalfa tips sectioned 4 days after having been infested with lygus bugs showed welldeveloped lateral buds at the same transverse plane as injured terminal buds. This condition indicates that a retardation of growth had resulted, with the lateral bud in the process of substitution for the injured terminal region.

Discoloration and disintegration of the tissue surrounding the point of penetration by the bug stylets through young protective leaves, which enclose the terminal meristem, were confined to a small area around the stylet punctures.

The daily growth increment of alfalfa plants, as measured by fresh or dry weight when compared with uninfested plants, was consistently reduced by 6,8 , or 16 bugs. Plants infested with 2 or 4 bugs were reduced 30 to 60 per cent in daily growth increment, as compared with uninfested plants, when the bugs were introduced within 4 days from the time of cutting.

In five of six periods, when 1 to 4 bugs were confined on alfalfa plant stems after they were 6 to 10 inches high, growth rate was not significantly less than with uninfested plants.

A decrease in growth as a result of an infestation of lygus bugs during one period did not substantially influence the growth rate of the plants during the succeeding period.

\section{ACKNOWLEDGMENTS}

The authors wish to express their appreciation to members of the Division of Plant Nutrition for the loan of greenhouse space and equipment and for their helpful suggestions on water culture methods; and to A. S. Foster and J. P. Bennett for their criticism of the manuscript. 
ARnon, D. I.

\section{LITERATURE CITED}

1938. Microelements in culture solution experiments with higher plants. Am. Jour. Bot. $25: 322$.

Carlson, J. W.

1940. Lygus bug damage to alfalfa in relation to seed production. Jour. Agr. Res. 61 : 791-815.

CARTER, WALTER.

1939. Injuries to plants caused by insect toxins. Bot. Rev. 5:273-326.

CASsidy, T. P., and T. C. BARBER.

1938. Hemipterous cotton insects of Arizona and their economic importance and control. U.S. Bur. Ent. and Plant Quar. series E 439:1-14.

1939. Hemipterous insects of cotton in Arizona: Their economic importance and control. Jour. Econ. Ent. 32:99-104.

CRAIG, R., and C. WILSON.

1937. The use of buffered solutions in staining theory and practice. Stain Technol. 12(3): 99-109.

EwING, K. P.

1929. Effects on the cotton plant of the feeding of certain Hemiptera of the family Miridiae. Jour. Econ. Ent. 22:761-65.

Hills, O. A.

1941. Isolation-cage studies of certain hemipterous and homopterous insects on sugar beets grown for seed. Jour. Econ. Ent. 34:756-60.

1943. Comparative ability of several species of Lygus and the Say stinkbug to damage sugar beets grown for seed. Jour. Agr. Res. 67:389-94.

Hoagland, D. R., and D. I. ARNoN.

1938. The water-culture method for growing plants without soil. California Agr. Exp. Sta. Cir. 347:1-39.

McGregor, E. A.

1927. Lygus elisus: a pest of the cotton regions in Arizona and California. U.S. Dept. Agr. Tech. Bul. 4:1-15.

Meyer, B. S., and D. B. Anderson.

1939. Plant physiology. 696 p. D. Van Nostrand Co., Inc., Inc., New York, N.Y.

MORRILL, A. W.

1917. Cotton pests in the arid and semiarid southwest. Jour. Econ. Ent. 10:310.

Pilkington, M.

1929. The regeneration of the stem apex. New Phytol. 28:37-53.

SHULL, W. E.

1933. An investigation of the Lygus species which are pests of beans (Hemiptera, Miridae). Idaho Agr. Exp. Sta. Res. Bul. 11:1-42.

Shull, W. E., P. L. RICE, and M. F. Cline.

1934. Lygus hesperus in relation to plant growth, blossom drop and seed set in alfalfa.

Sмiтh, G. L. Jour. Econ. Ent. 27(1):265-69.

1942. California cotton insects. California Agr. Exp. Sta. Bul. 660:1-50.

SORENSON, C. J.

1932. Insects in relation to alfalfa seed production. Utah Agr. Exp. Sta. Cir. 98:9-11.

1936. Lygus bugs in relation to occurrence of shriveled alfalfa seed. Jour. Econ. Ent. $29: 454-57$.

1939. Lygus hesperus Knight and Lygus elisus Van Duzee in relation to alfalfa-seed production. Utah Agr. Exp. Sta. Bul. 284:1-61.

StitT, L. L.

1940. Three species of the genus Lygus and their relation to alfalfa seed production in southern Arizona and California. U.S. Dept. Agr. Tech. Bul. GDvs1-19. 


\section{PLATES}





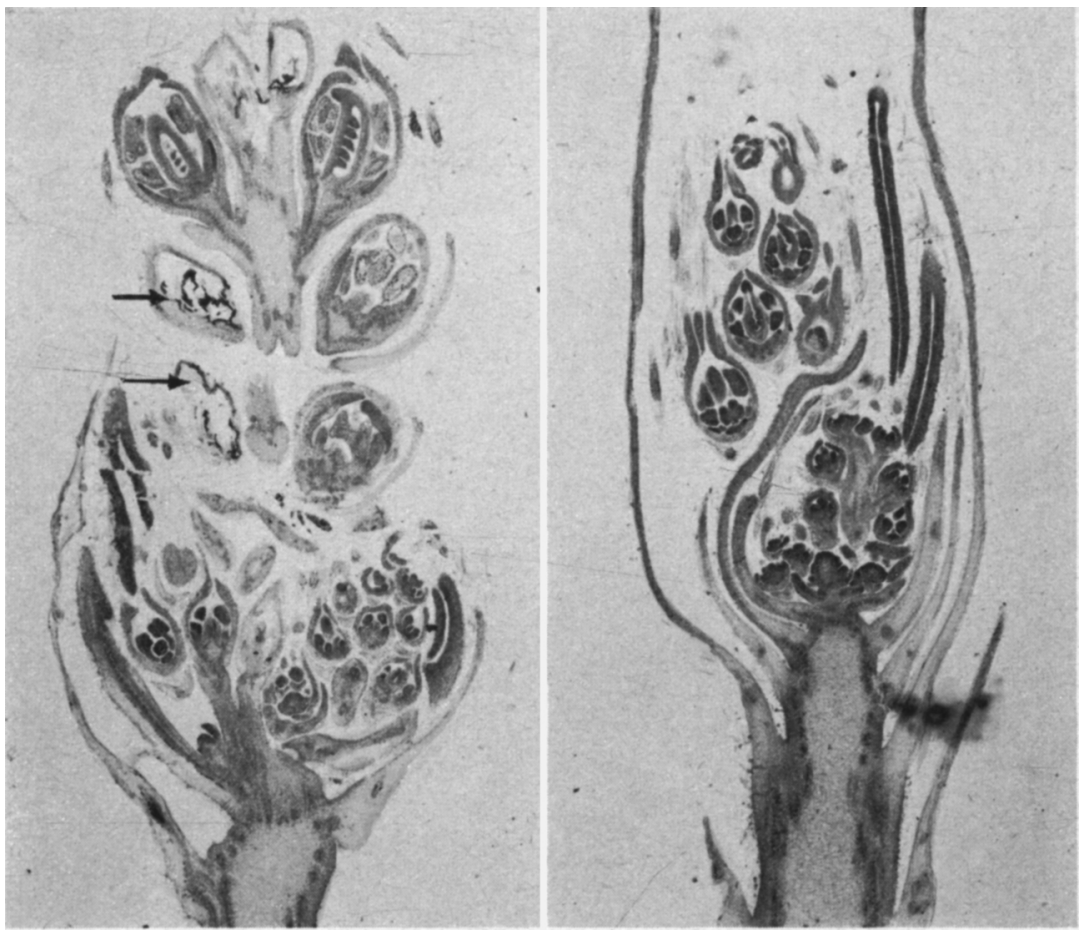

Plate 1.-A, Photomicrograph of a longitudinal section through a young alfalfa raceme injured by lygus bugs. Arrows show disintegrated ovaries. $B$, Longitudinal section through an uninjured young alfalfa raceme. $(X 14$. 


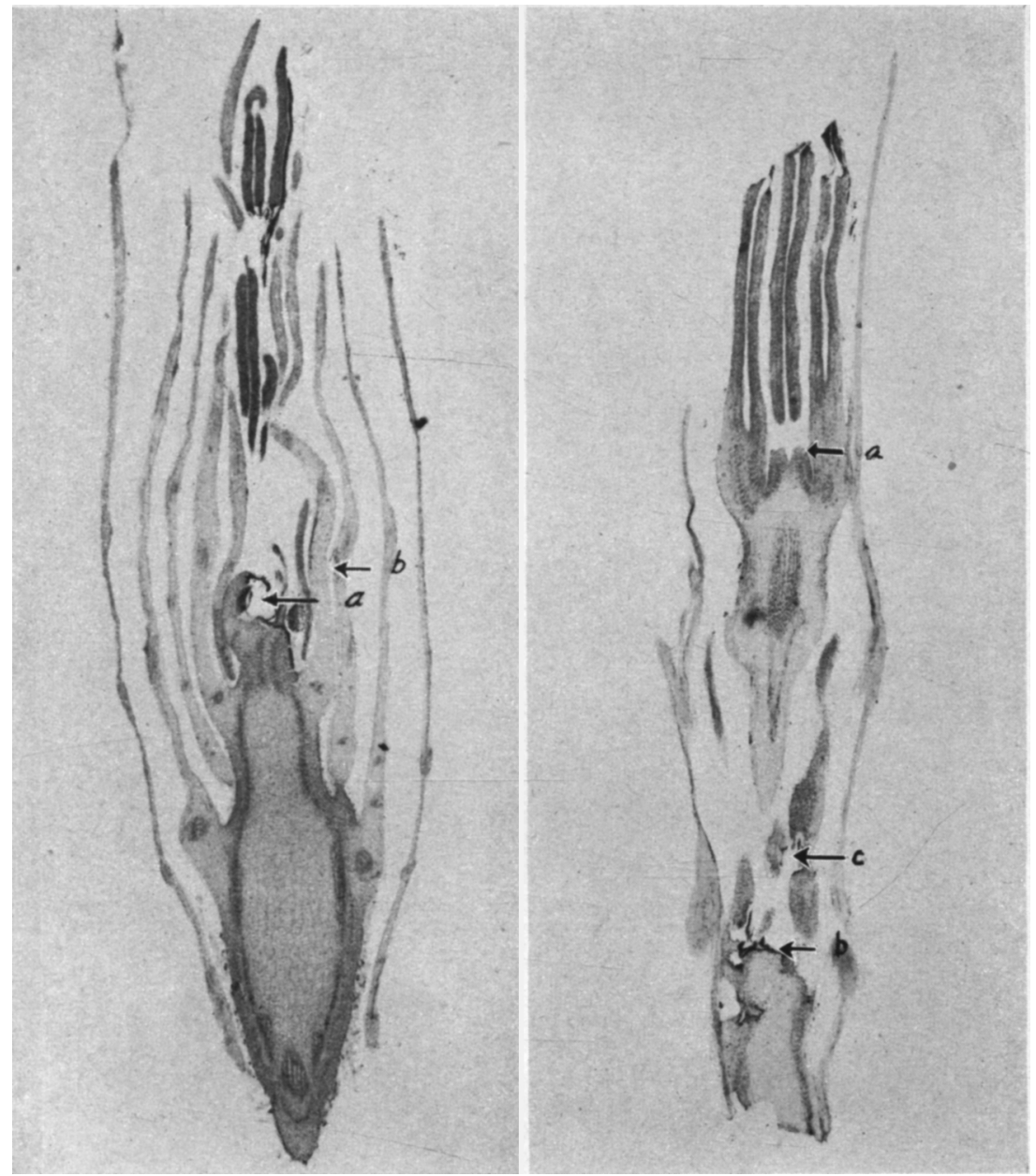

Plate 2.-A, Photomicrograph of a longitudinal section through an alfalfa bud in the vegetative growth stage showing $(a)$ disintegrated terminal meristem resulting from lygus bug feeding, and (b) path of stylets through protective leaf. $B$, Longitudinal section through a severely injured bud in vegetative growth stage 6 days after infestation, showing $(a)$ formation of new uninjured terminal growing region after the old one $(b)$ had been destroyed, and $(c)$ injury to young leaf. $(\times 16$. 


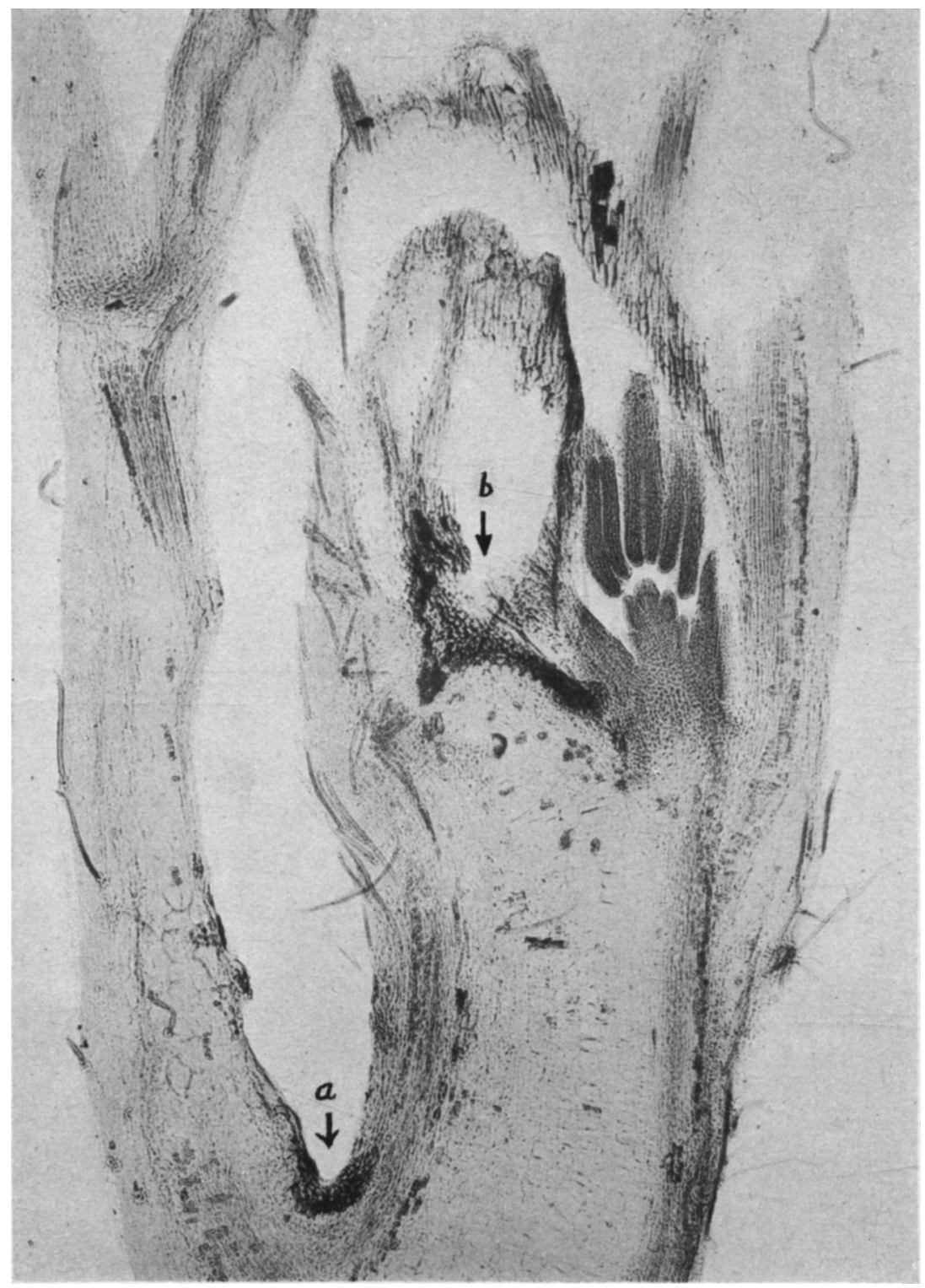

Plate 3-Photomicrograph of a longitudinal section of an alfalfa bud injured by lygus bug feeding, showing disintegrated terminal growing region $(b)$ and lateral bud $(a)$. At the right is an uninjured lateral bud apparently in process of being substituted for injured terminal growing region. $(X 43$. $)$ 


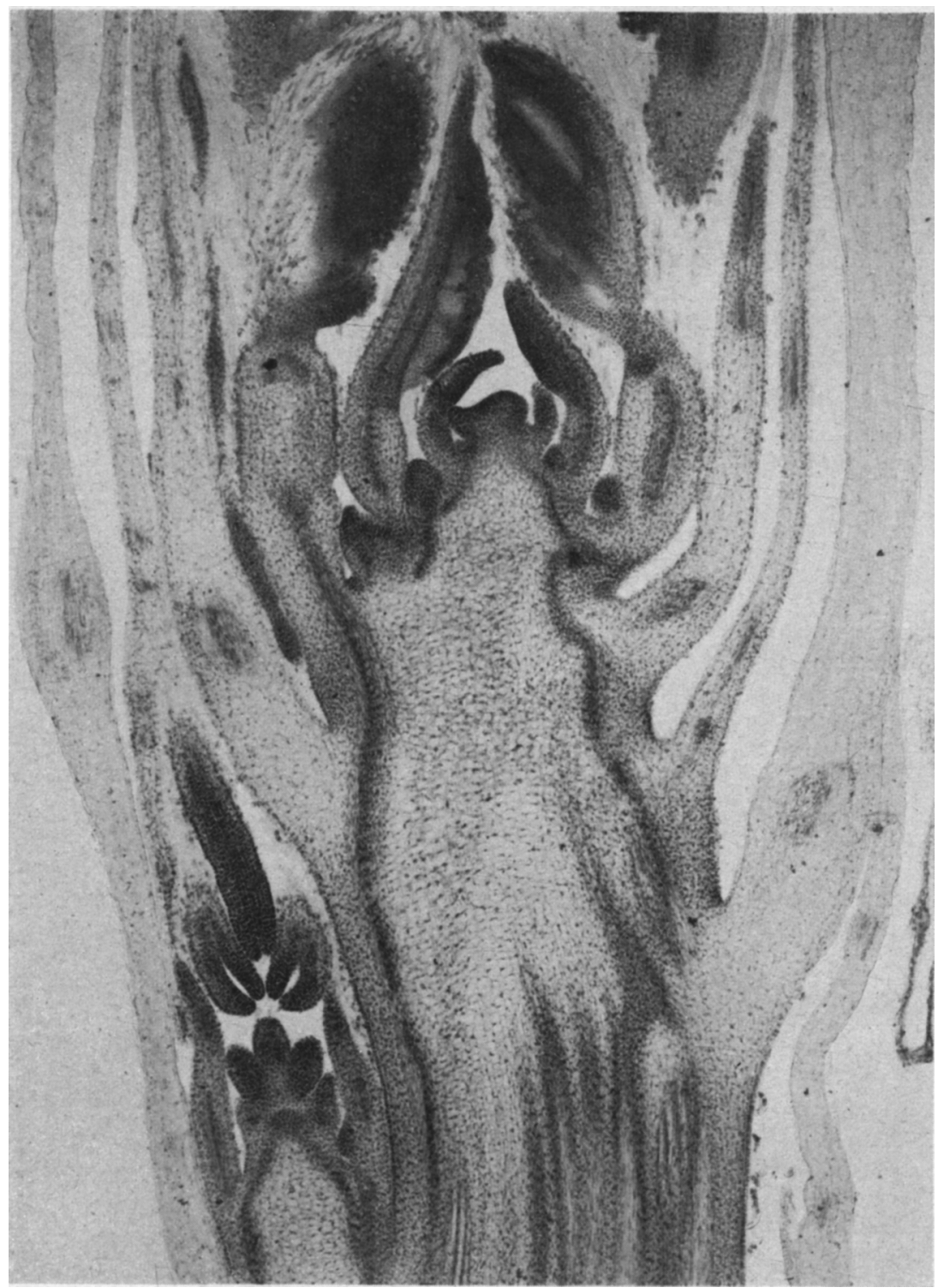

Plate 4.-Photomicrograph of a longitudinal section of a normal alfalfa tip. Note growing apex with leaf primordia and successive stages in the formation of axillary buds, appearing first as dark-stained meristematic cells in the axils of young leaves. $(X 46$. 